\title{
Digital Representation of 1:1,000,000-scale Hydrographic Areas of the Great Basin
}

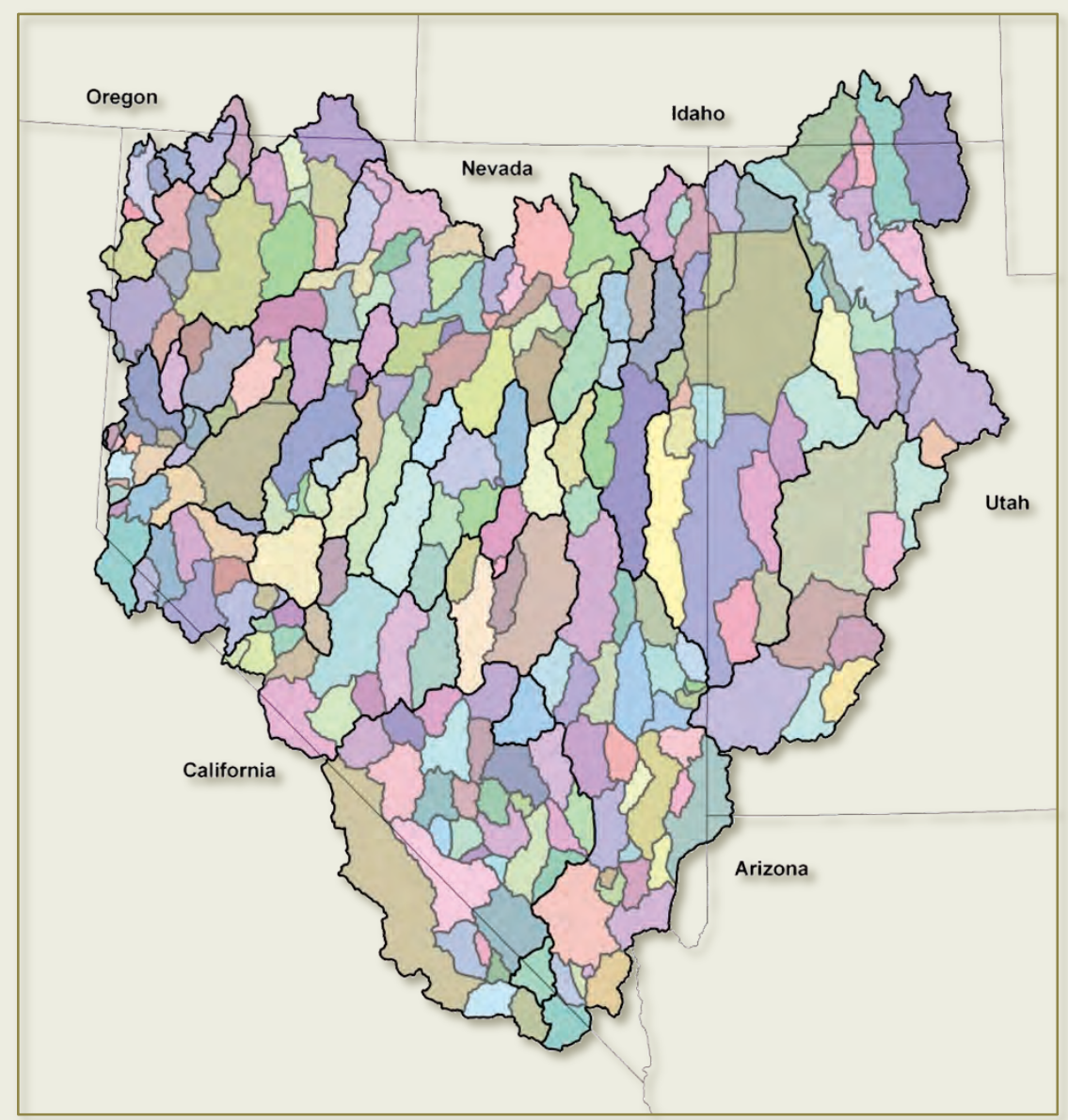

Data Series 457 
Cover: Map showing 1:1,000,000-scale Great Basin hydrographic area dataset 


\section{Digital representation of 1:1,000,000-scale Hydrographic Areas of the Great Basin}

By Susan G. Buto

Data Series 457

U.S. Department of the Interior U.S. Geological Survey 


\section{U.S. Department of the Interior \\ KEN SALAZAR, Secretary}

\section{U.S. Geological Survey \\ Suzette M. Kimball, Acting Director}

U.S. Geological Survey, Reston, Virginia 2009

For product and ordering information:

World Wide Web: http://www.usgs.gov/pubprod

Telephone: 1-888-ASK-USGS

For more information on the USGS-the Federal source for science about the Earth, its natural and living resources, natural hazards, and the environment:

World Wide Web: http://www.usgs.gov

Telephone: 1-888-ASK-USGS

Suggested citation:

Buto, S.G., 2009, Digital representation of 1:1,000,000-scale Hydrographic Areas of the Great Basin: U.S. Geological Survey Data Series Report 2009-457, 5 p; Available at http://pubs.usgs.gov/ds/457

Any use of trade, product, or firm names is for descriptive purposes only and does not imply endorsement by the U.S. Government.

Although this report is in the public domain, permission must be secured from the individual copyright owners to reproduce any copyrighted material contained within this report. 


\section{Contents}

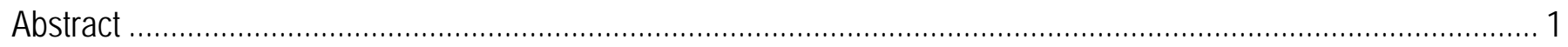

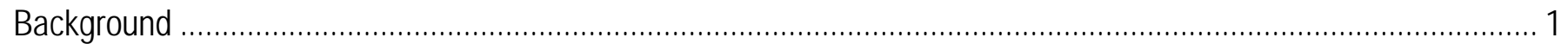

Development of the Great Basin Hydrographic Area Digital Dataset......................................................... 2

Differences between Nevada and Great Basin Hydrographic Areas................................................................ 4

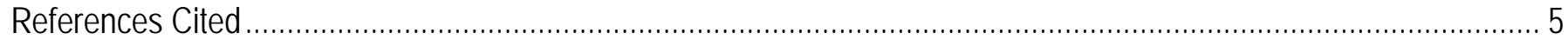




\title{
Digital Representation of 1:1,000,000-scale Hydrographic
}

\section{Areas of the Great Basin}

By Susan G. Buto

\begin{abstract}
Hydrographic areas (HA) in Nevada were delineated by the U.S. Geological Survey (USGS) and Nevada Division of Water Resources in the late 1960s for scientific and administrative purposes. The official HA names, numbers, and boundaries continue to be used in USGS scientific reports and Nevada State Division of Water Resources administrative activities. HAs for the Great Basin region of the United States were mapped in the late 1980’s as part of a USGS regional assessment of aquifer systems in the Great Basin. The Great Basin HAs are being published in digital format to document the data as the basic accounting unit for past and recent hydrologic investigations in the Great Basin.
\end{abstract}

\section{Background}

Hydrographic areas (HA) in Nevada were delineated by the U.S. Geological Survey (USGS) and Nevada Division of Water Resources in the late 1960s (Cardinalli and others, 1968; Rush, 1968) for scientific and administrative purposes. The official HA names, numbers, and boundaries continue to be used in USGS scientific reports and Nevada State Division of Water Resources administrative activities. Generally, the topographic and geologic features that constitute the geographic boundaries of HAs 
correspond to hydrologic boundaries (Harril and others, 1988). Hydrographic area boundaries may also include arbitrary administrative or political divisions. The Nevada HAs were published in digital format at 1:750,000-scale by the USGS in 2005 (Peltz and others, 2005).

HAs for the Great Basin region of the United States were mapped in the late 1980's as part of a USGS regional assessment of aquifer systems in the Great Basin (RASA). The map, published as a USGS Hydrologic Investigations Atlas (HA-694-C; Harrill and others, 1988), covers parts of Nevada, California, Idaho, Oregon and Utah. The Great Basin HAs were developed to maintain the naming and numbering system that was widely used in Nevada for hydrologic investigations in the larger area of the Great Basin. The Nevada HAs are a subset of the Great Basin HAs and may differ slightly from those boundaries. Significant differences between the Nevada and Great Basin HAs are outlined later in this report. The Great Basin HAs are being published in digital format to document the data as the basic accounting unit for past and current hydrologic investigations in the Great Basin.

\section{Development of the Great Basin Hydrographic Area Digital Dataset}

A paper copy of 1:1,000,000-scale HA-694-C sheet 2 was scanned at 400 dots per inch on a large format scanner. The map image was georeferenced to Lambert Conformal Conic projection. Georeferencing was done using digital points representing the corners of USGS 30 by 60 minute topographic quadrangles matched to corresponding locations on the map image. The scanned image was rectified using first order polynomial transformation with a RMS error of approximately 90 meters. The hydrographic area boundaries were digitized into a line feature class using the rectified basemap as a guide. The index map on sheet 1 of HA-694-C was used as a guide to identify the location of hydrographic area boundaries on the more complex sheet 2. Hydrographic area boundary lines present on the index map were missing, illegible, or incomplete on sheet 2 in several instances. In most cases, the missing boundaries were either estimated from ancillary information mapped on sheet 2 or derived 
from the 1:750,000-scale digital Nevada hydrographic areas (HA-750; Peltz and others, 2005).

Hydrographic area boundaries visible on the index map but missing on sheet 2 were not included in this dataset in three instances. The lines were omitted because there was no basis for estimating an accurate boundary based on information on the 1:1,000,000-scale map or other data sources. These instances and the reasons for their omission are as follows:

1. The index map on sheet 1 divides Dayton Valley (hydrographic area 103) into two subareas. Because the lines are not present on HA-694-C - sheet 2 and do not exist in HA-750, these division lines were left out of the digital dataset.

2. The index map divides Utah Valley (hydrographic area 265) into three subareas. The lines are not present on HA-694-C - sheet 2. Because HAs outside the State of Nevada are not available from HA-750 the division lines were left out of the digital dataset.

3. The index map divides Quinn River Valley (hydrographic area 33) into three subareas. The lines for subarea C are not evident on HA-694-C - sheet 2. Because HAs outside the State of Nevada are not available from HA-750 the division lines were left out of the digital dataset.

Polygons were created from the digitized line data. Polygon attributes, including hydrographic area and flow system names and numbers, were added to the polygon dataset. The polygon attributes were populated based on the index map and list of names presented on sheet 1 of HA-694-C. Two typographic and cartographic errors were found on the index map. The errors are as follows:

1. HA 121 - Soda Spring Valley is divided into three subareas on the index map: 121A - Eastern Part, 121B - Western Part, and 121C - Central Part. The list of HA names on sheet 1 mistakenly identifies 121B as both the Western subarea and as the Eastern subarea. The digital data set uses the convention from the index map. 
2. HA 164 - Ivanpah Valley is divided into two subareas on the index map: 164A - Northern Part, and 164B - Southern Part. The numbers are reversed on the HA name list on sheet 1 . The digital data set uses the convention from the index map.

The digital dataset can be downloaded from the USGS at http://water.usgs.gov/GIS/metadata/usgswrd/XML/ha694c_ha1000gb.xml.

\section{Differences Between Nevada and Great Basin Hydrographic Areas}

Boundary delineations differ between the Nevada and Great Basin HA datasets because of scale differences. The Nevada HA data were derived from 1:750,000-scale maps and the Great Basin data were originally mapped at 1:1,000,000-scale. The Great Basin HA naming and numbering system is similar to the system on the Nevada HA map but some differences exist. Notable differences are as follows:

1. Great Basin HA 254 - Snake Valley is composed of three valleys in the Nevada HA map: HA 196 - Hamlin Valley, HA 194 - Pleasant Valley, and HA 195 - Snake Valley.

2. Great Basin HA 243 - Death Valley is composed of two valleys in the Nevada map: HA 231 Grapevine Canyon, and HA 232 - Oriental Wash.

3. Great Basin HA 280 - Beryl-Enterprise Area is HA 197 - Escalante Desert in the Nevada map.

4. Great Basin HA 48 - Tenmile Creek Area is named "Dixie Creek-Tenmile Creek area" in the Nevada map. The HA number is the same in both maps.

5. Great Basin HA 252 - Pilot Valley does not exist in the Nevada map. The area is part of Nevada HA 192 - Great Salt Lake Desert. 
6. Great Basin HA 261A - Great Salt Lake Desert (West Part) is HA 192 - Great Salt Lake Desert in the Nevada map.

7. Great Basin HA 251 - Grouse Creek Valley is HA 190 - Grouse Creek Valley in the Nevada map. The Southwestern boundary of this area is delineated differently in the Nevada map.

8. Great Basin HA 253 - Deep Creek Valley is HA193 - Deep Creek Valley in the Nevada map.

\section{References Cited}

Cardinalli, J.L., Roach, L.M., Rush, F.E., and Vasey, B.J., 1968, State of Nevada hydrographic areas, scale 1:500,000, in Rush, F.E., ed., Index of hydrographic areas: Nevada Division of Water Resources Information Report 6, 38 p.

Harrill, J.R., Gates, J.S., and Thomas, J.M., 1988, Major ground-water flow systems in the Great Basin region of Nevada, Utah, and adjacent states: U.S. Geological Survey Hydrologic Investigations Atlas HA-694-C, scale 1:1,000,000, 2 sheets.

Peltz, L.A., Medina, R.L., and Buto, S.G., 2005, 1:750,000-scale hydrographic areas and basin-wide pumpage, recharge and interbasin flow estimates of Nevada: U.S. Geological Survey vector digital data, http://water.usgs.gov/GIS/metadata/usgswrd/XML/nv_ha750nv.xml

Rush, F.E., 1968, Index of hydrographic areas in Nevada: Nevada Division of Water Resources Information Report 6, 38 p. 